\title{
Chapter 8 \\ The Many (Still) Functional Housing Estates of Bucharest, Romania: A Viable Housing Provider in Europe's Densest Capital City
}

\author{
Vera Marin and Liviu Chelcea
}

\begin{abstract}
Housing estates built during the post-World War II decades in many countries have followed diverging trajectories. These include maintenance and repair, demolition, 'doing nothing,' and demolition with mixed-usage replacements. Drawing on empirical and historical material from Bucharest, Romania, a city in which $80 \%$ of the housing stock consists of socialist era housing estates, we argue that such housing continues to be viable and is even enjoying a minor renaissance, mainly through the financial efforts of residents and, occasionally, through the allocation of a certain amount of public funds. The empirical analysis illustrates that it is neither the mass character of such housing, nor its high-rise nature that creates the problems and negative image often associated with housing estates elsewhere in the world. Rather, we outline seven challenges faced by such estates: ageing of their structure and resident population, networked connectivity, energy efficiency, densification, urban planning that favours real estate agents, neglect of housing policies and housing rights, and condominium governance. The housing estates and their problems are so much a part of everyday normality in Bucharest that the local administration tends to take them for granted and has not placed them on the public agenda despite the inevitability of their structural decay at some time in the future. More than anything else, the state and the owners need to gather data in order to preempt future emergencies or continuing physical decay of this valuable housing stock.
\end{abstract}

Keywords Housing estates - Housing policy - Mass housing - Material culture Eastern Europe · Bucharest

\footnotetext{
V. Marin · L. Chelcea $(\square)$

Bucharest, Romania

e-mail: liviu.chelcea@sas.unibuc.ro

V. Marin

e-mail: vera.atu@gmail.com

(C) The Author(s) 2018

D. B. Hess et al. (eds.), Housing Estates in Europe, The Urban Book Series,

https://doi.org/10.1007/978-3-319-92813-5_8
} 


\subsection{Introduction: A City With Many Housing Estates}

In the early 1970s, at the time when the Pruitt-Igoe housing estate was being demolished with explosives in St. Louis (Fishman 2004; Freidrichs 2011) and housing estate construction in France was losing momentum (Cupers 2014a, b), a 300.000-inhabitant housing estate (Balta Albă) was being completed in Bucharest. This large neighborhood and a number of smaller (but still with more than 100,000 inhabitants) housing estates constructed in the 1960s, 1970s and 1980s account for a staggering 80 to $82 \%$ of all buildings in Bucharest and some $83 \%$ of the city's population, according to the 2011 census (INS 2011). By comparison, the share of housing estates in the total housing stock is 40 to $50 \%$ in other large cities of Central and Eastern Europe, and less than $10 \%$ in the countries of Western Europe (van Kempen et al. 2005).

Prefabricated housing estates constructed in cities all over the world after the conclusion of World War II have followed divergent trajectories. In Great Britain, the US, the former German Democratic Republic (Bernt 2009), as well as in Moscow, Russia (Luhn 2017) a number of housing estates have been demolished. In other parts of the world, they have been demolished and replaced with new apartment buildings, usually for wealthier families (Lees et al. 2008, p. 112). A 'do nothing' policy on the part of authorities and gradual deterioration has often been the fate of housing estates. In France, however, the state has continued to invest in maintenance and repair and housing estates remain viable (Wacquant 1993). In Romania, a 99\% privatisation rate in the early 1990s (INS 2011) led to dwellings in apartment buildings becoming the responsibility of the households who own them but who do not always possess the culture, knowledge or financial resources for property management (but who, nonetheless, cherish their apartments). Far from entering a downward spiral, as some scholars rightly feared in the early 1990s (Andrusz 1996), the collective housing estates in Bucharest are highly functional. Despite their problems, and despite class-based criticism of collective housing by upwardly mobile individuals and the cultural bourgeoisie, housing estates are neither pockets of poverty, ghettos, sites of social uniformity, or crime-ridden slums, nor do they carry 'territorial stigma' (Wacquant 1993). An appreciation of living in a large socialist-era housing estate even shows up in TV series, music, blogs, and visual arts projects (Dumitru 2016). Accommodating a large majority of Bucharest inhabitants in privately owned apartments, they are a good illustration of a combination of a public (mostly) 'do nothing' approach while private (but occasionally public) maintenance and repair are also important.

Although housing estates have problems (which we later describe in detail), most real estate transactions in Bucharest involve housing estates. Banks have not redlined them. Moreover, they are socially mixed, containing low- and medium-income households. They are liked by their residents, their population tends to be stable, and demolishing them is not even close to appearing on the 
public agenda. ${ }^{1}$ On the contrary, having lately attracted modest public funding, housing estates are enjoying something of a renaissance. Although some of their residents dream of higher quality housing, housing estates have kept their value, and this situation ought to be judged not against a 'growth' assumption (i.e. 'an expectation of moving up the housing ladder') but against several realities: the virtual absence of construction of new public housing; evictions from nationalised housing; the fact that almost 50\% of the country's population live below the poverty line; and, the tragic condition that approximately $5 \%$ of Romania's population live in squats, shanties, and other makeshift housing (Berescu et al. 2006). Moreover, the new residential ensembles are not necessarily better (although they are certainly flashier), since they have been built fast, construction legislation is weakly enforced, and the provision of urban services is sometimes deficient.

The data that we use come from a variety of sources. For her doctoral research (Marin 2009), Vera Marin interviewed approximately 30 architects, policy makers, representatives of condominium associations, and advocacy groups. A mapping instrument was assembled to analyse the state of the housing estates in Bucharest. We also reviewed plans, legislation, and strategic documents. Additional data come from capacity building activities organised for representatives of condominium associations, as well as for applied research carried out in the development of a new edition of the Master Plan of Bucharest (2014). We have also used 2002 and 2011 aggregate census data, which, as we explain in the last section of the article, are unfortunately a weak descriptor of housing estate residents, as census tracts do not overlap with apartment building groupings. This reflects the lack of interest in housing in the post-socialist period, when housing stopped being a right and became a merit-based good. We also mention that Bucharest's administration does not own or provide much data, as housing is, compared to private transportation for instance, at the bottom of the priorities list in many ex-socialist countries (Tuvikene 2018; Chelcea and Druță 2016).

\subsection{Growth of Bucharest's Housing Estates in Four Periods}

Buildings providing collective housing first appeared in Bucharest at the end of the nineteenth century on the Hausmannian boulevards that opened up the city (e.g. B-dul Elisabeta, B-dul Carol). Prior to World War II, these were low-rise detached buildings with gardens. Both the central government and various major economic actors (e.g. Romanian Railway Companies) developed affordable social housing programs, but these were very low-density (one or two storeys high) and very few in number compared with what was to come.

\footnotetext{
${ }^{1}$ There are rumours that the administration of District 5 plans to demolish Zăbrăuți, one of the poorest, if not the poorest, mikrorayons in Bucharest (see Florea 2017).
} 
The population of Bucharest grew from around 1,025,000 inhabitants in 1950 to around 1,366,000 in 1960 and around 1,800,000 in 1975 (Marin 2009). In 1990, the population reached 2 million. With the exception of the 1950s, when the old, centrally located housing stock absorbed a migration wave through housing nationalisation (Chelcea 2012), most of this population growth was housed in newly built housing estates (see Figs. 8.1 and 8.2). It was a period of continued industrialisation, carried out following very centralised decision-making processes in city planning and placing a large emphasis on efficiency in producing large numbers of standard housing units made with prefabricated elements.

It is possible to identify four fairly distinct periods in the production of mass housing in Bucharest. Each of these stages will be briefly discussed in this section, and we explain shifts in related political and economic conditions. The short-lived but intense changes that took place during the period 1950-1955 correspond with

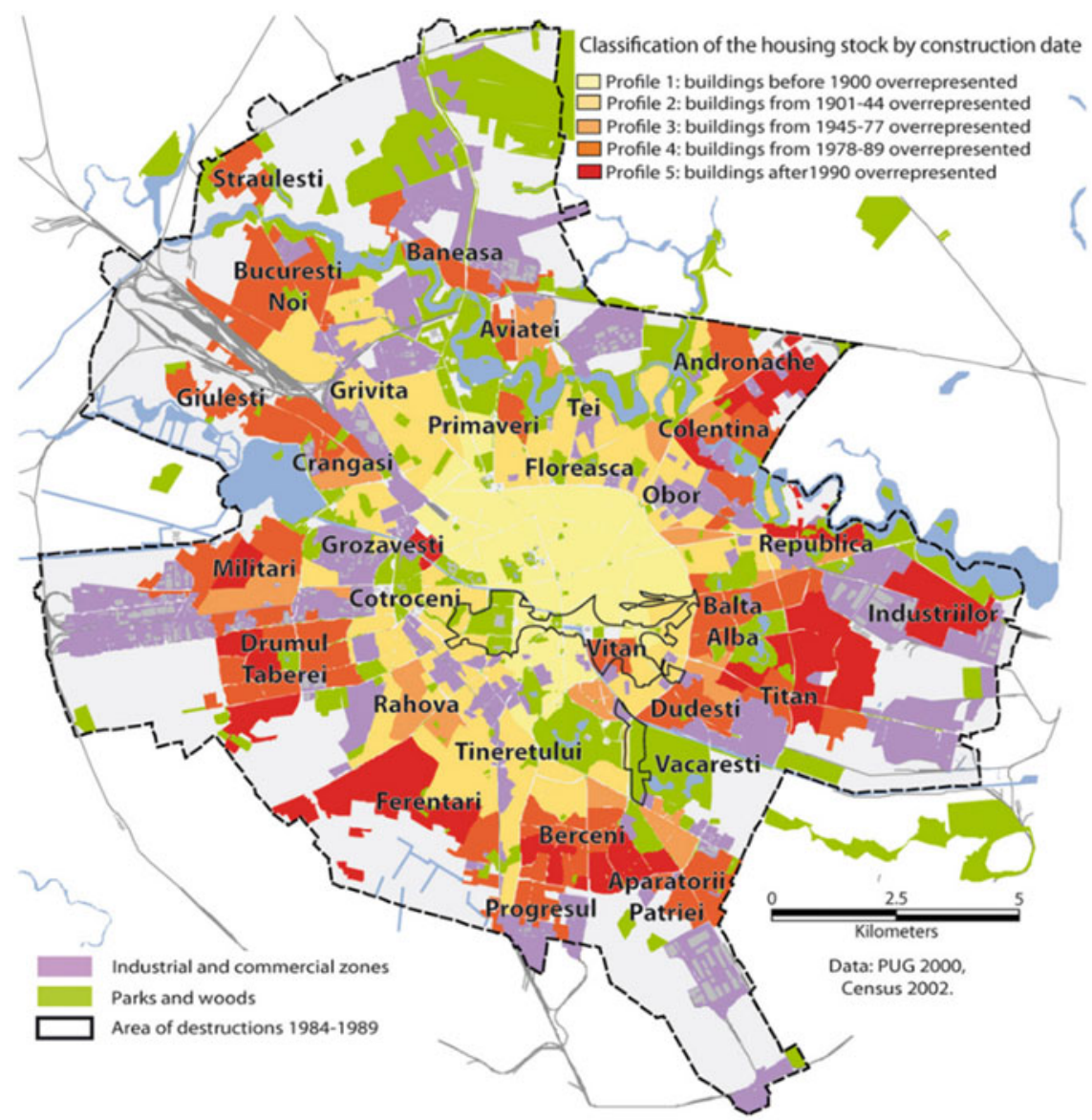

Fig. 8.1 Land use and building age in Bucharest. Source Direcţia Urbanism şi Amenajarea Teritoriului 2000; INS 2002, Marcińczak et al. 2014 


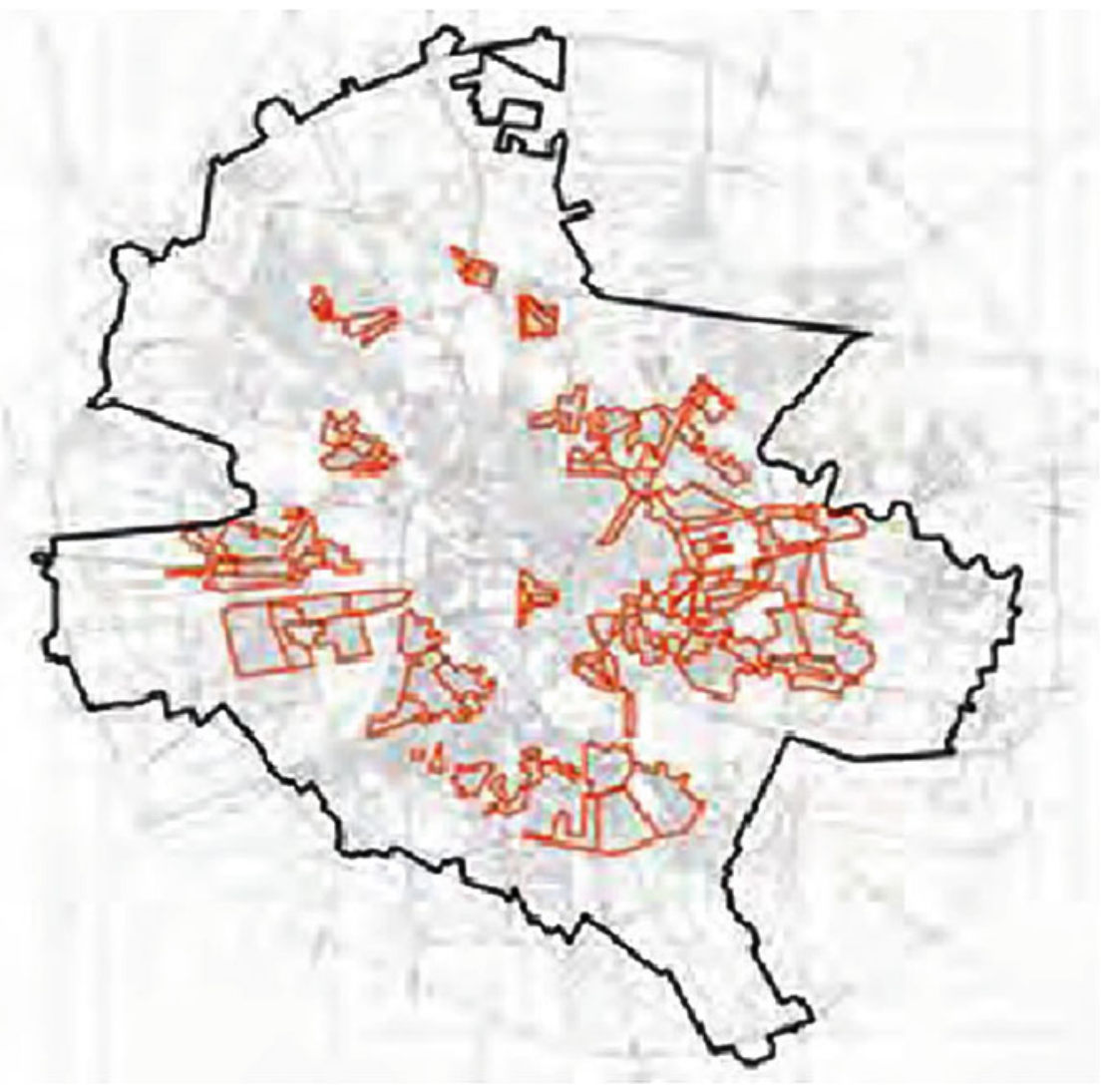

Fig. 8.2 Location of pre-1990 housing estates. Source Personal analysis Vera Marin, based on https://cadastral.github.io/

the appropriation of Soviet housing policy. From 1956 to 1977, there was a certain opening toward the principles of the functionalist city. From 1977 to 1990, housing policy reflected significant austerity measures (see also Fig. 8.1). The construction of housing estates ceased after 1990. It was only after economic growth and the development of the securitised market in mortgages that former industrial sites in large cities were transformed into new privately developed residential ensembles.

\subsubsection{5-1955: Introduction of High-Quality Small-Scale Housing Estates}

Immediately after World War II, the socialist state began to pay more attention to large-scale collective buildings, using the cvartal model as developed in the Former Soviet Union. These were massive buildings for their location (of 3-5 storeys, see Fig. 8.3), 


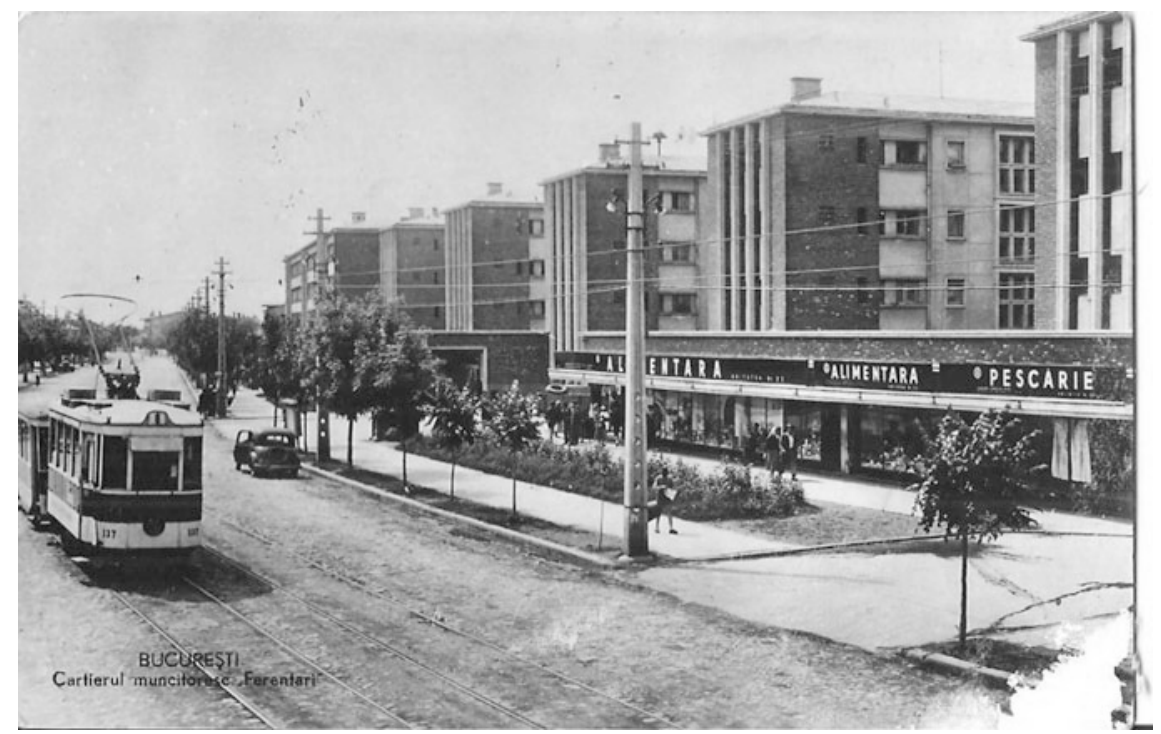

Fig. 8.3 A Cvartal in a poor working-class neighbourhood (Ferentari), 1950s. Source https:// www.okazii.ro/cpi-b4447-bucuresti-cartierul-muncitoresc-ferentari-circulata-stampila-1960-tramvaia166487002, public domain

which were sporadically inserted into low-rise working-class and middle-class areas in Bucharest. They were imagined as 'Palaces for workers,' so they were designed with grandiose entrances, arches and columns, multiple staircases, and an inner courtyard with a generous garden (see Fig. 8.4). They were high-quality buildings; to this day they are highly sought after, even if the apartments are small (Tudora 2003). Housing construction attracted increased attention during that period. In 1950, the local administrations were permitted to establish construction companies, and, in the following years, plans aimed to intensify housing construction. The scope of these interventions was, however, modest, compared with what was to come. In 1954, for instance, only 1,000 apartments were produced (Marin 2009).

\subsubsection{6-1977: Quality in Mass Housing}

Beginning in the late 1950s, and then in full force during the 1960s and 1970s, the socialist state substantially financed urban renewal plans based on functionalist principles. 'Systematisation,' as urban renewal was called, was meant, according to Gheorghe Gheorghi-Dej, the head of the ruling party at the time, to deliver 'constructions that are cheap, good and beautiful, which contribute to the embellishment of the cities. For the towns and cities which do not have yet the systematisation plan, a detailed systematisation plan will be made for the pieces of land that will be 


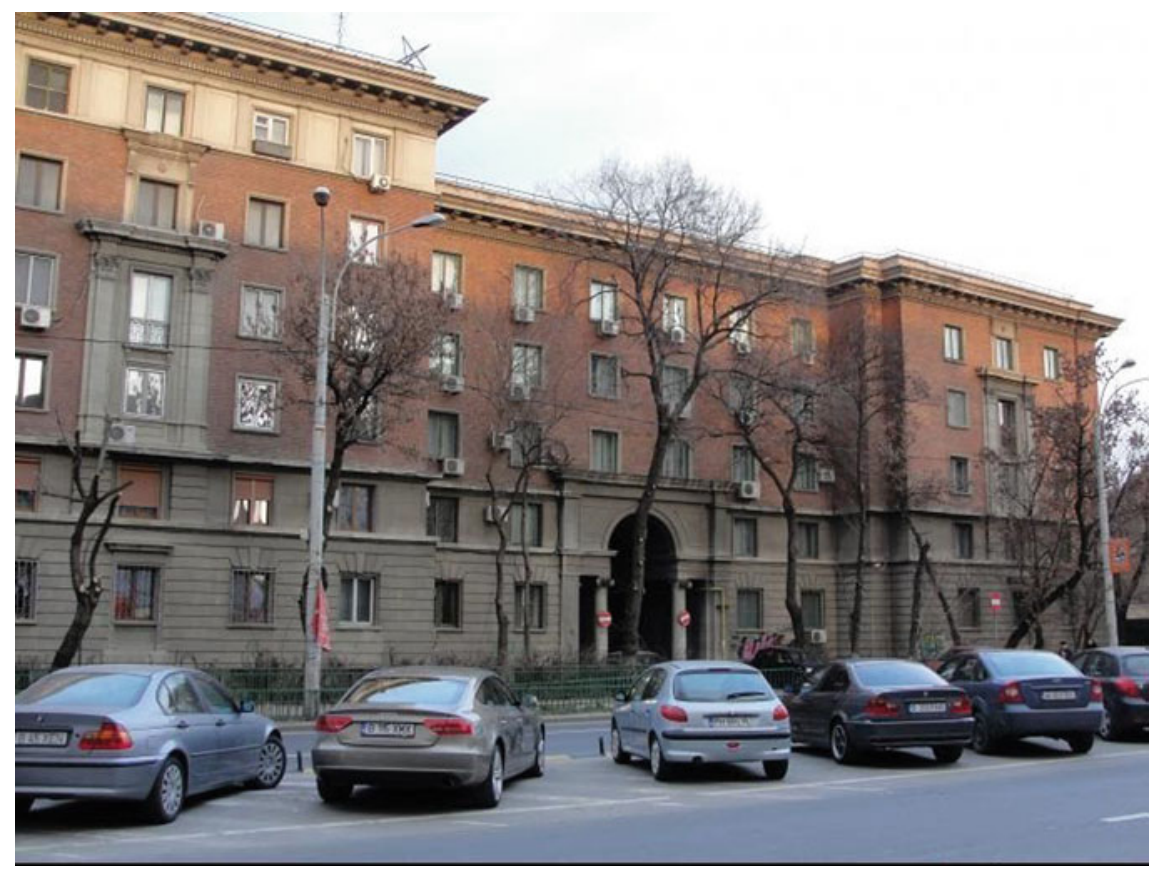

Fig. 8.4 A 1950s-era Cvartal building near a pre-war middle-class neighbourhood (Cotroceni). Source http://wikimapia.org/17751797/ro/Corpul-BC, public domain

used.' These plans aimed to deliver 300,000 units between 1960 and 1965 and subsequently 100,000 per year (Locuința urbană 1962). These ambitious plans followed developments throughout Eastern Europe and even beyond, where the 'socialist modern' style of mass housing production-echoing 'international modernism'-became the norm (Fehérváry 2013, p. 82). As Krisztina Féherváry (2013, p. 83) notes, 'this style of architecture was not unique to socialism. In the 1960s, governments from London, Copenhagen, and New York City to Moscow and Bombay looked to new, prefabricated housing technologies to solve urban housing shortages.' On a more general level, they were inspired by the 5th Congress of the International Union of Architects; the decision makers and professionals were looking for a rational system inspired by Clarence Perry's neighbourhood units. If, in the late 1950s, housing construction policies focused on producing more units, from 1958 onward, as can be seen in Fig. 8.5, collective consumption functions and utilities also began to receive more attention (Gusti 1962; see Stroe 2015 for an analysis of housing policy at that historical juncture).

In the late 1960s and early 1970s, enormous housing estates were built in Bucharest. These included Titan, Drumul Taberei, Pantelimon and Colentina, with populations ranging from 150,000 to 300,000 inhabitants. They followed a nested hierarchy of density and concentration of functions. Playgrounds, kindergartens and primary schools were built for concentrations of buildings housing up to 1,500 


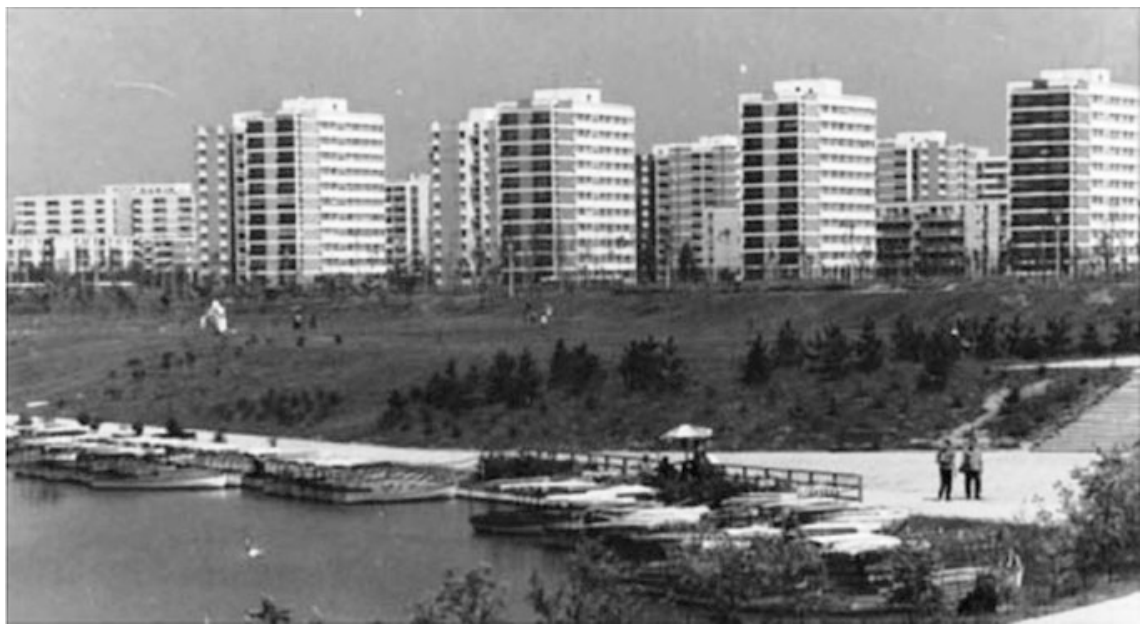

Fig. 8.5 A large housing estate (Balta Alba/Titan) built in the early 1970s providing accommodation for approximately 300,000 inhabitants. Source http://turismistoric.ro/wp-content/uploads/ 2015/08/61453699.jpg, public domain
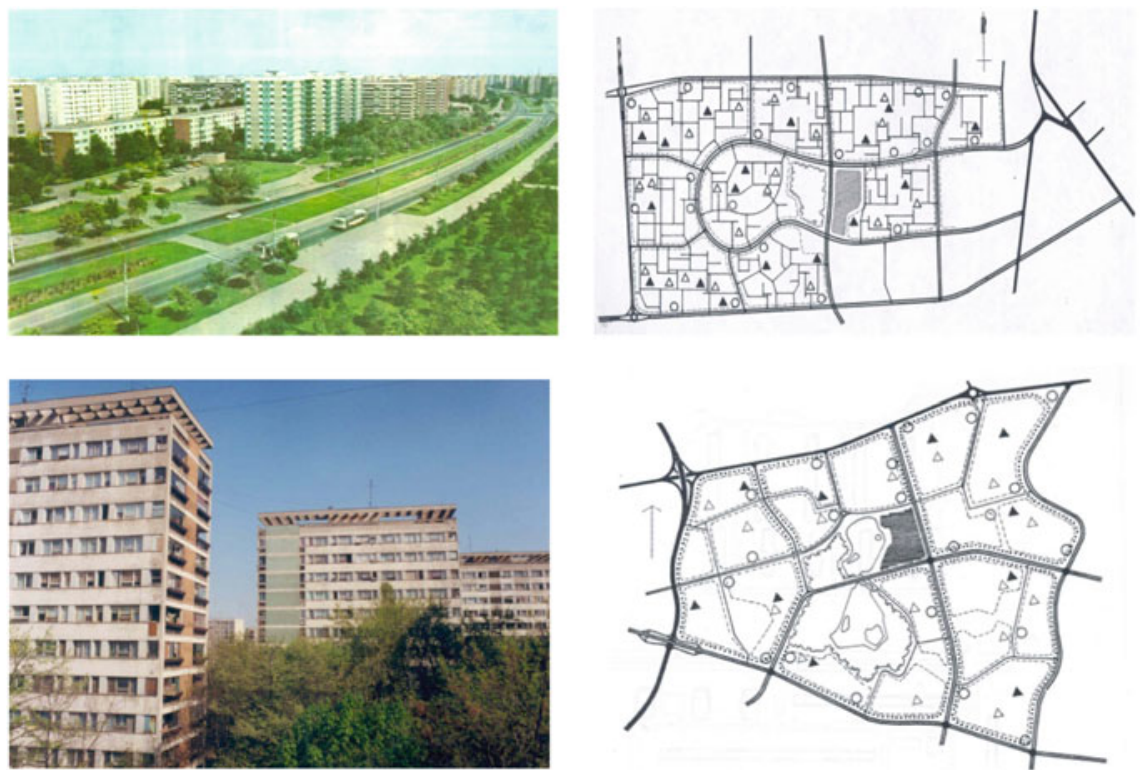

Fig. 8.6 Images and plans of two huge housing estates of the early 1970s, Drumul Taberei (upper images) and Balta Albă (lower images). Source "Locuinţa urbană,"1962, public domain 

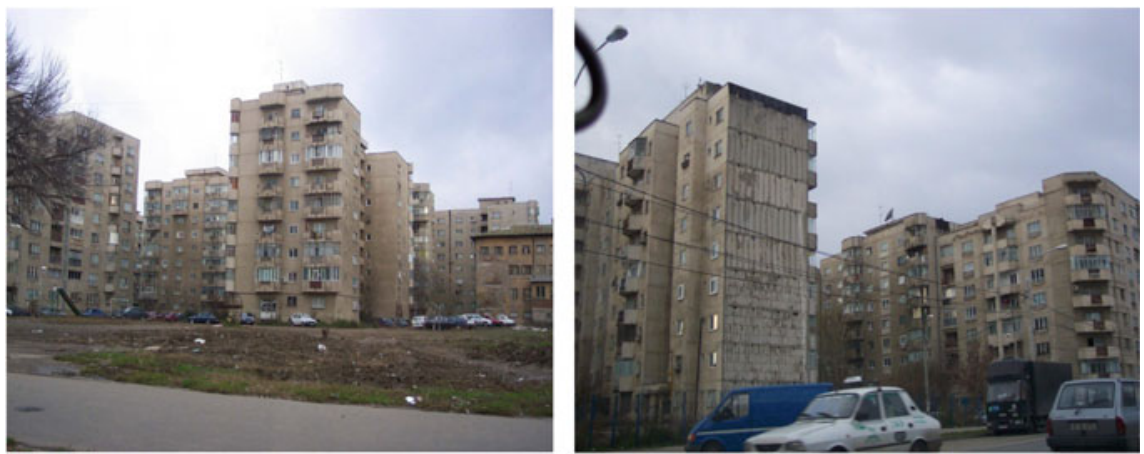

Fig. 8.7 Apartment buildings (in poor condition) from the 1980s on Calea 13 Septembrie. Source Author's images

people. Several such units, jointly accommodating 4,000 to 12,000 residents, formed a mikrorayon, and were outfitted with food, clothing, and shoe shops, restaurants, libraries, cultural centres, sports facilities and medical centres. A cluster of mikrorayons housing up to 40,000 inhabitants made up a rayon, which required secondary schools, sporting facilities, cinemas, post offices and hospitals. Finally, an agglomeration with over 40.000 inhabitants needed a theatre, a concert hall, a university, parks, hospitals and offices for state institutions. The buildings were simple, with large windows that opened onto large green spaces (see Figs. 8.6, 8.7, 8.8 and 8.9), with natural ventilation for bathrooms and with balconies and pantries.

As Krisztina Féherváry (2013, p. 86) reports for Hungary (though similar dynamics apply for Romania) 'compared with crowded living arrangements in village houses, which usually had no indoor plumbing and often still had packed-earth floors, a new apartment with an indoor toilet, running water, and heating seemed an undreamed-of luxury.' One gets a glimpse of that in the 1976 movie Serendă pentru etajul 12 (Serenade for the 12th floor) (see Boboc 2016, p. 94). On the other hand, not all planned collective consumption facilities were actually built, leading to serious frustrations for the population in the austerity decade of the 1980s. These ensembles are, nevertheless, still appreciated and various surveys indicate that people who grew up in these areas want to remain in them, not only because of family ties but also because of childhood nostalgia. Hipster bookstores in central Bucharest sell magnets with 1970s images of such districts to their youthful clientele. The way people inhabit apartments in housing estates is a good illustration of the saying 'My home is my castle' (Soaita 2012; Druṭă and Ronald 2017). As Krisztina Féherváry (2013, p. 16) explains, 'people strove to transform the interiors of apartments into heterotopic private spaces utterly distinct from the buildings that surrounded them,' in stark opposition to the 'perception that these public spaces ... belonged to an impersonal, unitary state.' Apartments were inhabited as spaces of 'normality,' clearly delineated materially, aesthetically, and politically from the abnormal politics present in the public space during the socialist and post-socialist periods (Fehérváry 2013, pp. 19, 29, 37). 
There is evidence for this in the attention paid to material and symbolic borders and thresholds, e.g. investment in massive apartment entrance doors, investments in double-glazed windows (Iancu 2011), or the separation ritual of taking off one's shoes as one enters the apartment (Fig. 8.6).

Usually, these high-rise estates were built in areas that were weakly or 'under'urbanised. Drumul Taberei, for instance, was built on former military space in the western part of the city. In 1974, however, the new urban planning legislation (Law 59/1974) stipulated more intensive use of land, so, especially after 1977 when an earthquake killed 1,000 residents of the central and semi-central areas, urban renewal plans began to address the older, semi-central, already urbanised core. Many buildings with long-expired lifespans were targeted for demolition and plans were made to rebuild from scratch. An old, centrally located radial, retail street (Calea Mosilor, though the same goes for Stefan cel Mare) was razed to the ground, enlarged and flanked by 10 -storey buildings.

\subsubsection{7-1990: Austerity, Poorer Quality and Densification}

The 1980s, a decade of IMF debt repayment austerity, import substitution, and the neo-Stalinist dictatorship of Nicolae Ceaușescu witnessed the densification of existing housing estates through inserts, generating poorer quality apartments. Compared to previous decades, the major differences of the late 1970s and 1980s are, in addition to densification, the shrinking of collective consumption facilities and a reduction in the level of attention paid to the quality and aesthetics of both urban composition and buildings themselves. That meant that balconies became smaller or disappeared altogether, the sizes of windows and green areas were reduced, and more exposed concrete was on view due to a lack of exterior plaster or paint. All of this materialised in poorer quality new housing, echoing, and probably exceeding, similar developments elsewhere in the region (in the former GDR and

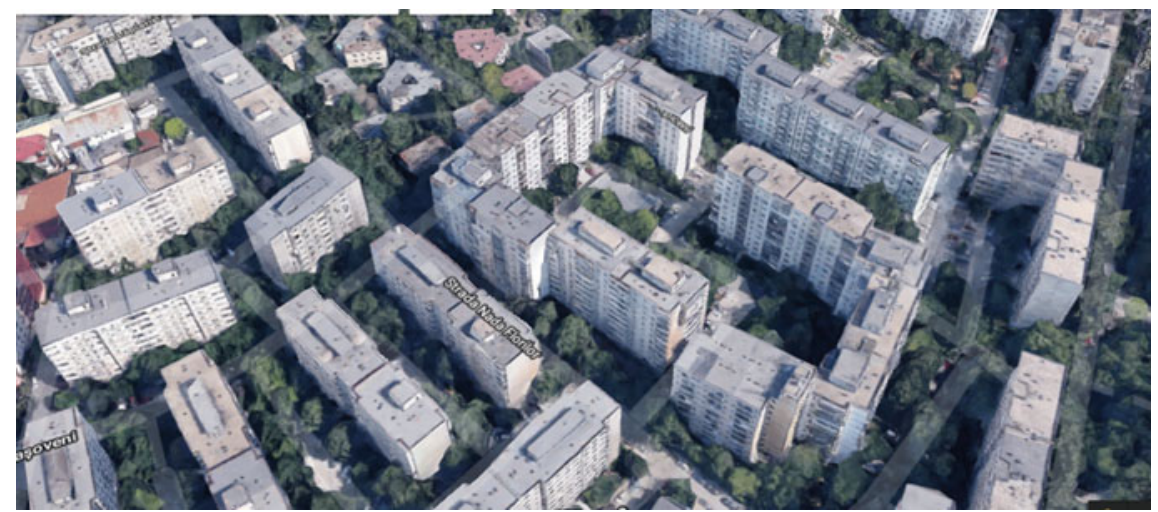

Fig. 8.8 Dense development, characteristic of the 1980. Source Google Maps 

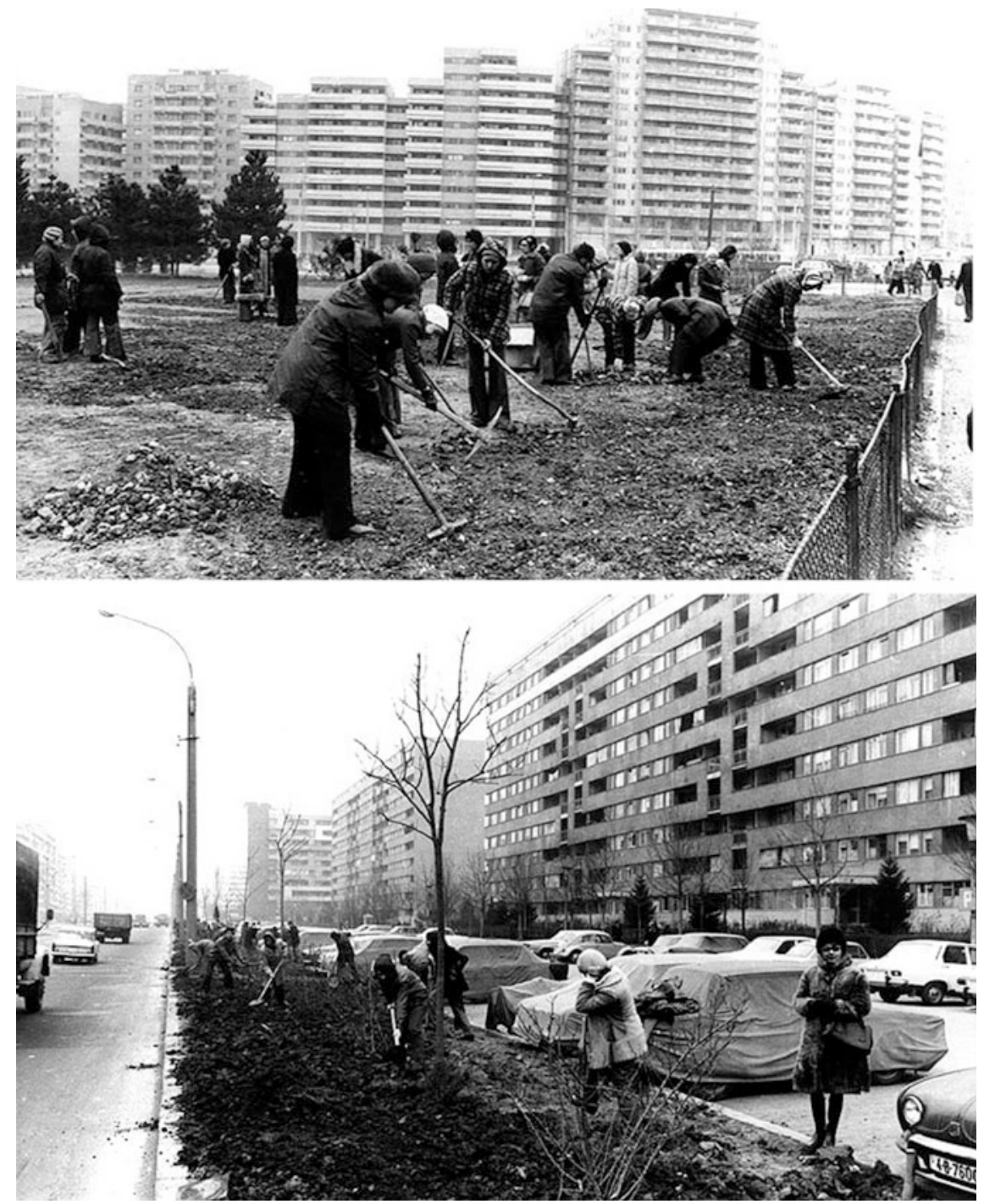

Fig. 8.9 "Voluntary" work by residents of a large housing estate (Lujerului), 1980s. Source Vera Marin, personal archive

Hungary, for instance (see Fehérváry 2013, p. 100). Buildings became twisted around small spaces, aggregated around a heating unit in the middle, or rather simple objects surrounded by barren land (see Fig. 8.7). The poor quality of public spaces was a contentious area in the politics of late socialism. Currently, the beautification of such spaces tops the list of ways in which local politicians go about accumulating political capital. Putting in grass playgrounds and painting buildings are very popular interventions with residents. 
Between 1960 and 1976 an average rayon or administrative district housed 10,000 inhabitants at a density of about 200-500 persons per hectare. In 1961, the average height of a building was 4.8 storeys. That rose to 6.8 storeys and was accompanied not only by a reduction in the space between buildings from twice the height to as little as the height but also by an increase between 1964 and 1975 in the maximum footprint from $10 \times 32 \mathrm{~m}$ to $18 \times 104.4 \mathrm{~m}$. The intensified construction of new apartment buildings among those constructed in the previous two decades meant a further distancing from the principles advocated by the functionalist movement. Berceni, a district in southern Bucharest, is a good example of this. Some parts of it were decent in the 1970s, but it is now the epitome of 1980s densification. These buildings conformed to more reliable seismic norms as far as their reinforced concrete structure was concerned. Rooms here were larger, however the poorer quality of their public spaces is reflected in their place in the housing market nowadays (see Fig. 8.8).

During the 1980s, schools and the municipal administration required inhabitants to engage in 'voluntary' work, usually to clean up green public spaces and parks. Article 8 of the decree 216/1981 imposed an obligation on citizens committees and building associations to clean public spaces and maintain and repair buildings and streets. Basically, this law forced everyone to become involved in the embellishment of the cities (see Fig. 8.9).

Also during the same period, some boulevards became simple 'canyons' with long rows of high-rise buildings on both sides, sometimes with very limited sidewalks (see Fig. 8.10). An exception not only in terms of quality but also in terms of design is the late 1980s 'civic center,' an aggressive urban renewal project that razed about a quarter of central and semi-central Bucharest.

\subsubsection{After 1990: The End of Mass Housing, Further Densification and Gated Communities}

At the beginning of the 1990s, the World Bank advised the former communist countries to privatise their housing units. Romanian municipalities sold these apartments very quickly to private parties. This is how private ownership skyrocketed to almost $100 \%$, practically overnight. After the 1990s, the massive allocation of state funds for housing, which, in previous decades had been around 8\% of GDP, ceased abruptly. In 1990, the ratio of privately financed to state-financed housing construction was 1:7; by 2008, that ratio had changed to 10:1 (Soaita 2012, p. 1014). Apart from the completion of structures already begun, there was very little construction of new mass housing. In the 1990s, there was timid real estate development and many urban dwellers returned to rural settlements (back to the regions where they were born). Others who preferred a house with a garden over mass housing ensembles moved to the sprawling suburbs if they could afford to do so.

It was only after 2005 that banks began to offer long-term mortgage loans. Apartments built then promised to change the image of the home from a refuge 


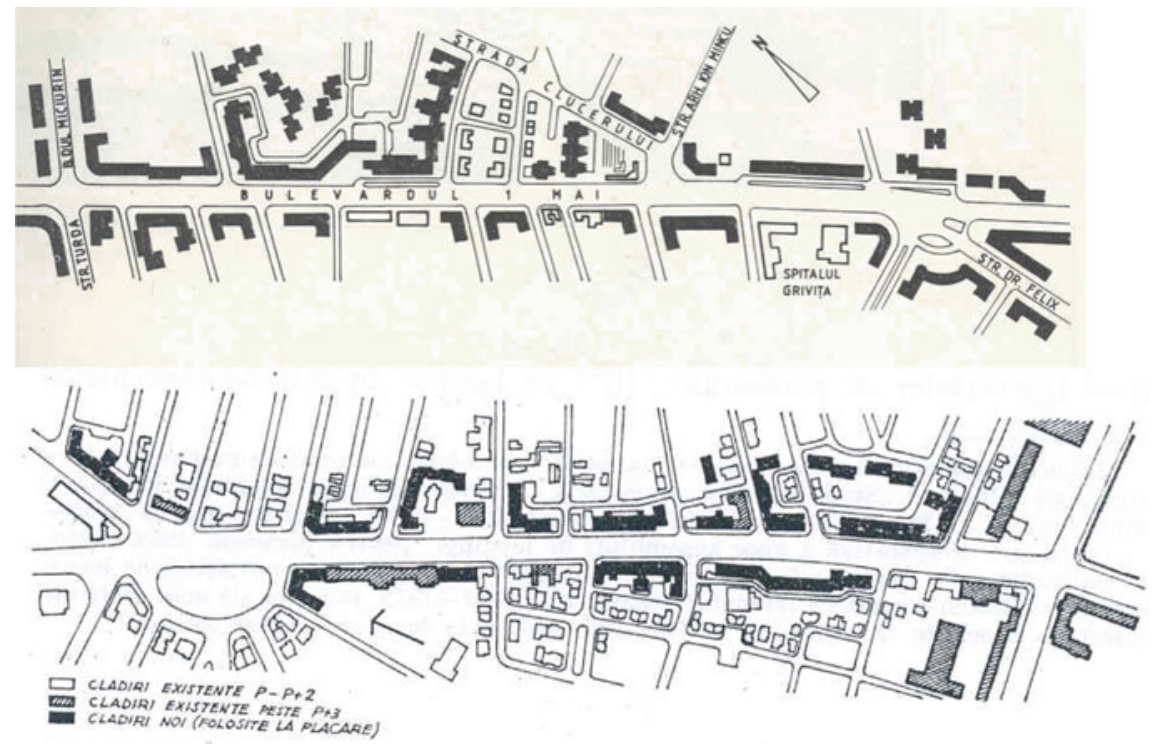

Fig. 8.10 Various 'canyon'-style configurations of apartment buildings along radial boulevards in old, low-rise, central areas of Bucharest (Bulevardul 1 Mai and Calea Mosilor). Source Marin 2009

from public space to a 'symbol of social success' (Boboc 2016, pp. 93-94). Less spatially concentrated and usually inserted into the older central and semi-central areas (Chelcea 2008), these new high-rises, designed as gated communities, replicated some of the negative planning and construction problems of the socialist housing estates. These included speed of construction, lack of integration with the surrounding space and lack of collective consumption facilities. If these new ensembles are built on brownfield sites, they rely on the already existing infrastructure (including utilities) of socialist-era housing estates. In the 1980s, it had been the (socialist) state that put pressure on urban planners to construct cost-efficiently; currently it is the developers who press for maximum profit (see Fig. 8.11). The layout of these new apartment blocks is sometimes less functional than those projected by the socialist-era state planning offices.

\subsection{Characteristics of Physical Layouts of Housing Estates: 'Surround,' 'Points,' 'Blades,' and 'Canyon'}

Despite the immense size of housing estates, their nested structure allows enough scope for variability. The mikrorayon sections of housing estates do not necessarily occupy a significant surface area. Rather, what sets these housing estates apart is their lack of integration with surrounding urban tissues and their dense occupation 


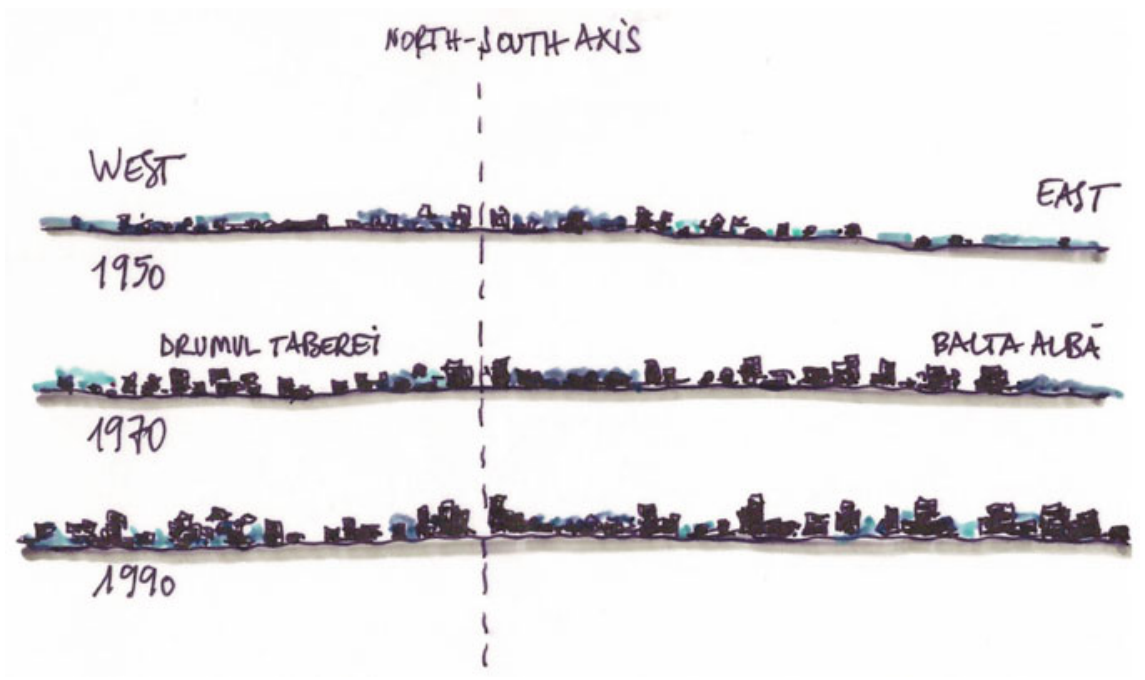

Fig. 8.11 Section profile of Bucharest at the inception and end of the high-rise era. Source Vera Marin, 2018

of urban land. At their inception, and throughout their gradual densification, housing estates came to have several kinds of physical layout. Based on Marin (2009), we distinguish four dominant types: (1) surround; (2) points and blades; (3) parallel blades; (4) canyon. Figure 8.12 illustrates the physical layouts that are commonly visible in the housing estates of Bucharest.

This bird's eye view of such housing estates suggests that the modernist ideology that underwrote them was fading away due to the pressures of densification. The public spaces - especially the green areas - are less generous than they were envisioned. Moreover, by the 1980s, the idea of building new collective housing areas with prefabricated panels had, by and large, been abandoned in much of Europe, though in Romania and other socialist countries, it was reaffirmed and remained the dominant housing policy (and even spilled over into some villages).

\subsection{Social Composition and Challenges Faced by Housing Estates}

At present - and it was probably even moreso at the time of their constructionhousing estates enjoy a high level of social mixing between professional ranks and middle-class positions (Marcińczak et al. 2014). Middle-income families often live next door to low-income families. Given the low level of residential mobility, some of the initial occupants still live in these apartments (Suditu et al. 2014). Historically, many of the apartments were acquired through a bank savings system, 

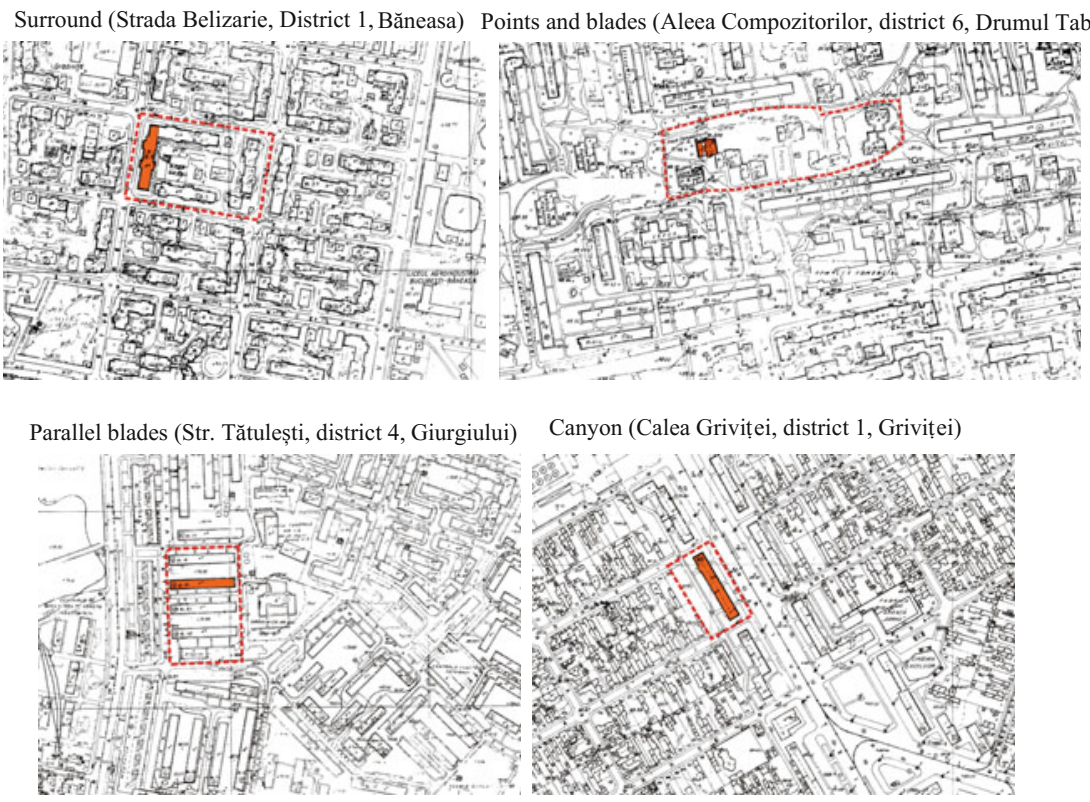

Fig. 8.12 Common physical layouts of buildings in Bucharest's housing estates. Source Marin, 2009

with mortgages usually lasting 30 years. Others were allocated as social housing to young workers, to newlyweds, and to those who had been relocated with their jobs to Bucharest. Retired people, as well as those earning less than a certain threshold, were allowed to rent apartments; those who earned more money were encouraged to start saving and then purchase apartments. Sizeable families were given priority. Some ministries developed their own housing programs in certain parts of Bucharest, as was the case with a number of mikrorayons in Drumul Taberei after 1963.

A lack of fit between census tracts and the boundaries of housing estate makes it difficult to provide a precise assessment of the exact number of residents, the share of minorities, and their economic status. Several conclusions can be drawn, however. First, tenure structure in housing estates is, of course, dominated by private ownership: units are mostly owner-occupied. Second, geographic distribution by education and profession, according to the 2011 census, suggests that the number of college-educated individuals is higher in central areas than in housing estates. Conversely, vocationally trained people occupy around $12.5 \%$ of the areas within housing estates, compared to $8.31 \%$ for the entire city and $2.22 \%$ for the central areas (INS 2011; in Chelcea et al. 2015).

The challenges faced by housing estates are obvious, as are the problems faced by the condominium associations, and local and central government. Seven such problems - the ageing of structures and the population; urban infrastructures and 
connectivity; energy efficiency; high densities; weak and pro-business planning; post-privatisation condominium administration and aesthetic challenges - are outlined below. Some of these issues may be relatively easily addressed (e.g. aesthetic problems), while some (e.g. high densities) require housing to be taken seriously as a right and an urban planning matter, rather than as a 'for-profit' domain outside the reach and scope of public policies. Here, we offer a brief account of each such challenge, as well as the programs and measures that it has attracted.

Ageing. The ageing problem in the housing estates is double-fold: it covers both the physical structures and the resident population. The original lifespan of the buildings has expired. When they were planned and erected, they were designed to last 50 years. This means that many of their functional systems (roofs, pipes, joints, etc.) need replacement. Second, 1992, 2002 and 2011 census data suggest that Bucharest's population is ageing. When the estates were built, $60 \%$ of the incoming residents were aged between 15 and 29 years old (Marin 2009). Although there has been generational replacement, some of the original population have now retired. This creates a host of planning challenges. For instance, many building are four storeys high and, as a rule, they do not have elevators. As a result, one may expect increasing mobility challenges for their occupants.

Urban infrastructure and connectivity. When first built, the apartments were fully integrated into networked infrastructures for water, gas, electricity and centralised heating, although the austerity decade of the 1980s created substantial service problems (see Chelcea and Pulay 2015). Owing to privatisation and deficient condominium management, some connectivity and building efficiency problems persist. For instance, the water company (Apa Nova Bucuresti, part of the multinational Veolia) is responsible for the upkeep of street water mains; water pipes inside the buildings, however, should be repaired and replaced by the condominium associations. Some associations are more proactive and replace them, while others lack either the resources or the trust required for the upkeep of the internal pipework (see Soaita 2012). The water company is currently trying to create a coalition of actors (condominium associations, Ministry of Development, and local government) for resource allocation for the replacement of pipes. As yet, these efforts remain a 'corporate social responsibility' of the water company, limited to the replacement of the pipes in 300 buildings in Bucharest. Some forms of 'splintering urbanism' (Graham and Simon 2001) have occurred. All apartments were scheduled for water metre installation (Bouzarovski 2009; Poputoaia and Bouzarovski 2010). Many households, especially in the late 1990s and the 2010s, rushed to disconnect from the centralised provision of heat and hot water. With the substantial increase in the price of natural gas, some have come to pay more for these services than they used to when they were connected to centralised networks, especially since the Bucharest municipality allocates more substantial subsidies for these services than other cities in Romania.

Energy efficiency. With $72 \%$ of its urban housing stock concentrated in housing estates, Romania had to address the issue of poor thermal insulation as part of its EU accession deal. Newly constructed buildings, most often in the form of detached housing, incorporate thermal insulation requirements from the moment of their 
construction. A more difficult challenge has been the retrofitting of existing buildings. One challenge has to do with the size of the buildings to be retrofitted. Although the average heated surface in apartments in housing estates is smaller than the heated surface in urban and suburban detached houses (48 sq. m compared to 73 sq. m), on average, apartment buildings in Romania contain 40 apartments each. Another challenge is regulatory. There are several central government agencies with overlapping authority over construction policy. They do not always cooperate and integrate their actions. There is, for example, no common nation-wide policy on what technologies and approaches should be used.

In addition to the size of the buildings and regulatory problems, another challenge is financial. Funds have not always been available, due either to the global financial crisis, or to there being other priorities. The apartment owners - the actual beneficiaries of this policy - have been unwilling to share even a small fraction of the costs of refurbishing their buildings. The shares of central government, local administration, and household contributions have varied. ${ }^{2}$ As a rule, household contributions have been minimal or not required. In some cases, the central government share was overwhelming, in others, the local government paid $100 \%$. In addition, quality issues have emerged. As thermal insulation is a recent addition to the activities of the construction industry in Romania, its financing has been sporadic, and the labour force is unfamiliar with recent technologies, companies that refurbish these apartment buildings have been charging substantial prices and have often placed substantial burdens on state budgets (for work of dubious quality). Finally, administrative knowledge (or lack of it) has been a further obstacle to progress with these buildings, although, starting from 2005, local authorities should have conducted an inventory of high-rise buildings in order to set criteria and establish priorities.

In Bucharest, as of $2011,21 \%$ of the housing stock had been retrofitted, which means 180,132 buildings out of a total of 844,586 (INS 2011). The poorest local government (District 5) had retrofitted only $16 \%$ of its buildings, while the richest (District 1) had retrofitted $28 \%$. Yet, there is hardly a linear correlation between the wealth of a district and the percentage of retrofitted buildings. A more fine-grained analysis is difficult, and this reflects not only scholarly difficulties, but administrative practices. Fieldwork evidence suggests that the choice of buildings for thermal insulation has been ruled by considerations of visibility (with buildings on main arteries attracting most investment), random criteria, or the persistence of the elected presidents of condominium associations. The criteria for prioritisation became looser and looser between 2002 and 2009, thus making a key dimension of targeted urban policies - slowing or reversing the downward spiral of certain struggling areas-impossible.

\footnotetext{
${ }^{2}$ Bucharest has two levels of governance: the general municipality and six district administrations. Their functions are sometimes distinct (e.g. the administration of some boulevards may lie with the general municipality; likewise waste collection) while at other times, they overlap (large-scale infrastructure projects).
} 
Density. A problem transcending political regimes and historical periods has been the high density of the population in housing estates of Bucharest (see Figs. 21 and 22 for bird's eye views of Drumul Taberei housing estate between 1966 and 2002). Bucharest is the most densely populated capital city in Europe with about 8,000 inhabitants per sq. km (Chelcea and Iancu 2015) and with particular areas inside the housing estates reaching a density of 13,000 inhabitants per sq. km (e.g. the Tineretului area and Lujerului area). Compared to housing estates in cities elsewhere in Europe, they feel rather cramped (see Fig. 8.13 for the evolution of Drumul Taberei). Even at their inception in the 1960s, when functionalist urban planning in Bucharest had some coherence, there was less green space and fewer collective consumption facilities than in cities such as Prague, Budapest and Kiev. The initial vision was to have 'cities within the city,' independent of the city centre and gravitating around large industrial areas. The above-mentioned Balta Albă neighbourhood - with its 300.000 inhabitants, many of whom worked in the nearby 23 August industrial area - was comparable in population size to Romania's second, third and fourth largest cities (Cluj, Timişoara and Iași, respectively). Despite that, it only had one movie theatre (Gloria) and one major department store (Magazinul Titan). Similar under-provision was evident in education. The cohorts that went to primary and secondary school in the 1980s remember that schools functioned in three shifts (early morning, afternoon and evening).

Densification continued in full swing even after the implosion of mass housing programs after 1989. After the rigid top-down approach that operated during Soviet times, urban planning in the 1990s changed to the opposite extreme. As in many places in Central and Eastern Europe, there was little or no urban planning at all in the 1990s. That meant that urban land could be speculated with in order to produce maximum profit. With no large housing estates being built inside or near Bucharest, two types of urban land became the major location for new buildings. First, due to de-industrialisation, industrial brownfields, which occupied about $15 \%$ of all urban land in Bucharest, were speculated for new condominium construction, most often in the form of gated communities (even if they were situated in central areas of Bucharest) (Chelcea 2008; Simion 2016). Not only did this increase the overall concentration of housing in socialist-era estates, but the densities inside such small-scale gated estates became similar to the areas they hoped to isolate themselves from, both physically and symbolically. Second, an unfortunate interpretation of restitution legislation allowed the construction of new buildings on green spaces populated with benches, playgrounds and gazebos lying between existing buildings (Hirt and Stanilov 2007). As Hirt and Stanilov explain (2007, p 228), 'as long as there were no buildings on the ground, the land was eligible for restitution. Since the laws allowed the restitution of almost any chunk of land, as long as there were no buildings upon it, neighborhood open spaces became legally eligible for private development.' Both brownfield conversion and restitution led the construction of new buildings. They tend to reproduce the shortcomings of the previous decades, adding more pressure on collective consumption (schools, kindergartens, 

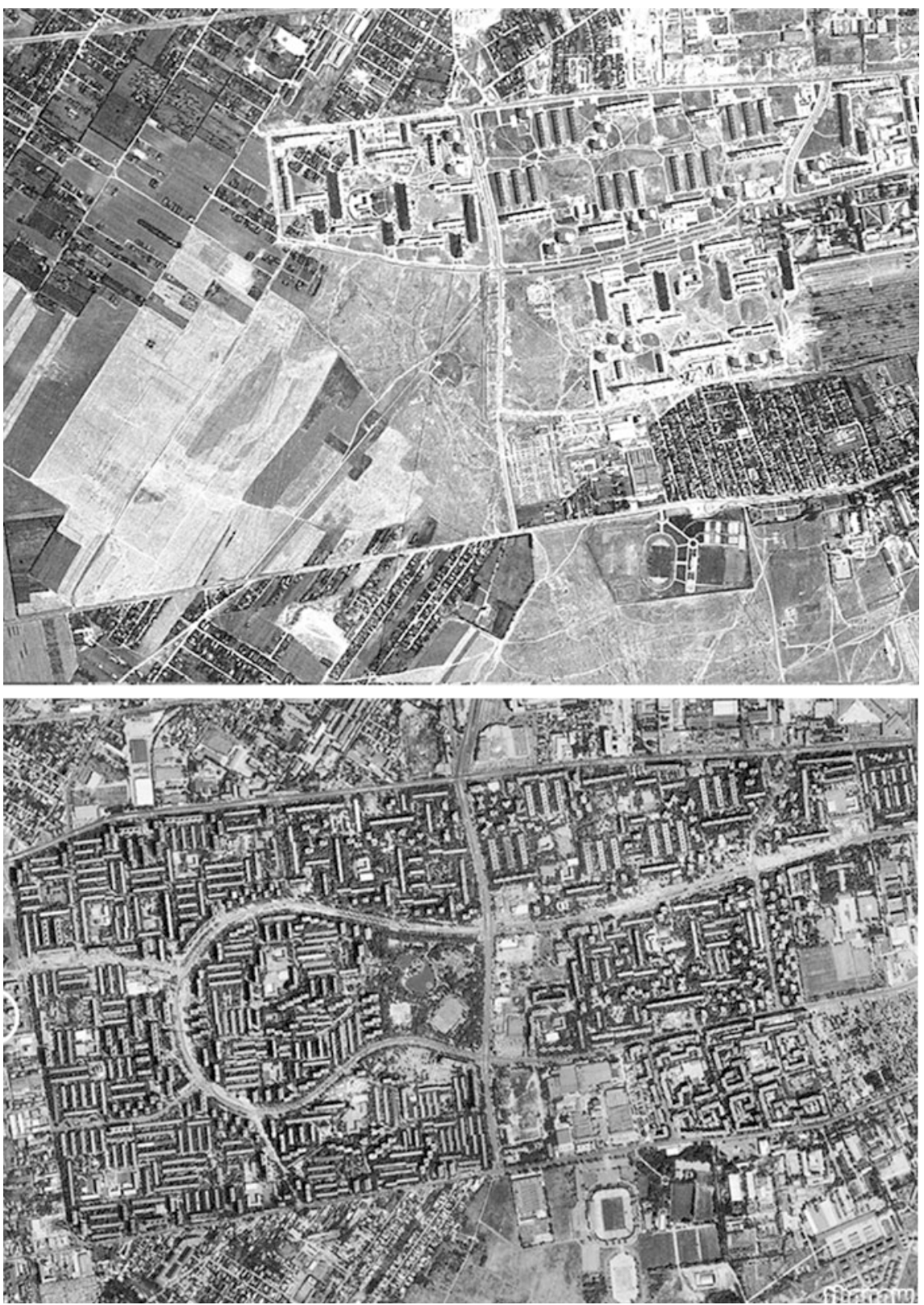

Fig. 8.13 Densification of Drumul Taberei Microraions between 1966 and 2012. Source http:// www.costingheorghe.ro/thenow/cartiere-dormitor-din-bucuresti/ 
and utilities) and intensifying automobile traffic and parking problems. One might imagine that density would eliminate inhabitants' reliance on their cars; however very often sidewalks are hijacked as parking lots, rendering them inaccessible to pedestrians. Since apartments in such buildings sell at higher prices than those in the 'old' socialist-era housing estates, they also increase urban segregation, often actively 'selling' segregation as a desirable trait.

Weak planning biased toward real estate developers. The further densification of housing estates after 1989 is also a symptom of weak urban planning, generally catering to the interests of real estate developers. A failure to find a balance between principles of urban planning and the private real estate business is due to insufficient community consultation, the softness of sanctions and weak municipal control of building activity. One example of such planning is the construction of large hypermarkets and shopping malls within already dense housing estates. In a truly dialectical manner, the under-provision of retail space during socialism has been used (and is still being used) as an argument for granting permits for large commercial investments, usually using industrial brownfield sites. Planning decisions of this kind have drastically intensified the heavy traffic in the already dense housing estates, as cars are parked, most often, directly on sidewalks.

Bolstering the importance of urban planning could follow two directions. First, public spaces might be easily improved. Local administrations have invested funds for such purposes, although public space has been shrinking constantly, both as a result of planning and spontaneously due to large pressure for car parking. Second, local administrations should invest more in collective consumption and urban functions. Education (especially nurseries and kindergartens), health, and sports facilities have been undersized from the inception of housing estates, and late-socialist and especially post-socialist densification has made the situation worse. To the extent that they have been created in the last two decades, such services and facilities are exclusively private, thus attracting only those who can afford them.

Housing is a low public agenda priority. Housing privatisation and the creation of a super-homeownership society were accompanied by the shifting of moral and financial responsibility from central government to the local authorities and then to the owners themselves. For some years after privatisation, this meant the withdrawal of any public subsidy for housing. From being a right, housing became an economic merit. Thus, a number of poor households became, as James Fearn (2004) argues, 'too poor to move, too poor to stay.' This is reflected, among other things, in the shape of census tracts. Many tracts include both housing estates and low-rise housing areas. Although often lumped together in uniform administrative categories, there are significant differences among structures in housing estates in terms of structural safety, energy efficiency, aesthetics, the financial power of owners and the efficiency of condominium associations. As they are privately owned, the administration places them outside its area of concern. This makes it difficult, for instance, to establish criteria and priorities for intervention and encourages ad hoc 
decisions that emphasise visibility. Some timid subsidies were reintroduced in the late 2000s, such as the subsidy for heating (since energy poverty is an important problem in Romania) (Buzar 2007).

Post-privatisation condominium governance. The mass privatisation of state-owned housing apartments in housing estates eliminated some problems and created others. For occupants of housing estates, it created protection against displacement and financial relief during the 1990s, a period of economic turmoil in Romania. Through housing privatisation, the cost of housing (at least) was written off for families struggling with shrinking social rights. As Stephens and Lux (2015, p. 1220) argue, 'giveaway privatisation thus created secure, debt-free home-owners, and played a crucial role in offsetting declining living standards arising from economic restructuring.' But it also meant a challenge to the administration of owner-occupied condominiums, including administrative efforts on behalf of new owners. Initially, all condominium associations were run by apartment owners, as they are legally non-profit organisations. Their scale may range from those apartments tied to a particular entrance in a building, to several neighbouring buildings linked by infrastructural nodes (such as a district heating system), proximity, or some other functional principle. One common problem has been the difficulty of actively prevailing upon their members to join in the election meetings, which has sometimes led to weak decision-making. Some residents could not afford to pay for utilities and had their apartments auctioned, others moved to the countryside, while yet others lived cramped together with their children in their apartments in order to make ends meet. Lack of trust between residents and the leadership of the association was also a problem (Soaita 2012, see also The Block, a documentary about condominium life in Romania, by Maria Sălaru). In the last 10 years, management companies began to emerge, assuming responsibility for accounting.

\subsection{Conclusion}

One may wonder what the appropriate course of action is for dealing with a large stock of apartments in vast housing estates. Should all apartment buildings in housing estates be maintained and repaired? Should they be left as they are? Should some perhaps be demolished completely or demolished and replaced with something else? Ironically, one cannot even speculate about this; first one needs to gather data in order to imagine solutions and perform administrative planning. Even if the state and the municipality allocated funds for thermal rehabilitation and built environment improvements (like the addition of playgrounds), prefabricated buildings were not built to last forever and even the most conscientious apartment owners will be overwhelmed at some point. The gloom and doom scenario outline by Andrusz (1996) may eventually come true in some areas. 
Our vision is that housing estates should be allocated public funds for maintenance and repair, but not to every owner. Public funds should be especially used to help low-income families, a strategy which will help maintain a social mix in Bucharest. If, however, there are solid arguments for demolition, under no circumstances should apartments buildings be demolished for the dispersal of poverty, unless better accommodation is offered to displaced lower class families.

Any properly grounded discussion about any policy will first need data gathering and data analysis, something that no public body is preoccupied with at the moment. In order to establish criteria, typologies and eligibilities, one needs to understand the broader vision for housing estates. Both the public authorities and the apartment owners are completely unprepared to ask uncomfortable questions and to allocate resources to seek answers.

Acknowledgements The authors would like to thank Daniel Hess, Tiit Tammaru, and Marteen van Ham for their help and suggestions.

\section{References}

Andrusz G (1996) Structural change and boundary instability. In: Andrusz G, Harloe M, Szelenyi I (eds) Cities after socialism. Blackwell, Cambridge, MA

Berescu C, Celac M, Ciobanu O, Manolache C (2006) Housing and extreme poverty: The case of Roma communities. Editura Universitara Ioan Mincu, Bucharest

Bernt M (2009) Partners for demolition: The governance of urban renewal in East Germany's shrinking cities. Int J Urban Reg Res 33(3):754-769

Boboc C (2016) Mare, curat și frumos. De la blocul comunist la ansamblul residential. In: Negru N (ed) Bucharest Housing Stories. Editura Pro Universitaria, Bucharest, pp 91-110

Bouzarovski S (2009) East-Central Europe's changing energy landscapes: a place for geography. Area 41(2):452-463

Buzar S (2007) Energy poverty in Eastern Europe: Hidden geographies of deprivation. Routledge, London

Chelcea L (2008) Bucureștiul postindustrial: Deindustrialiare, memorie și regenerare urbană. Polirom Iași

Chelcea L (2012) The housing question and the socialist answer: city, class and state remaking in 1950s Bucharest. Int J Urban Reg Res 36(2):281-296

Chelcea L, Druță O (2016) Zombie socialism and the rise of neoliberalism in Central and Eastern Europe. Eurasian Geogr Econ 57(4-5):521-544

Chelcea L, Iancu I (2015) An anthropology of parking: Infrastructures of automobility, work and circulation. Anthropol Work Rev 36(2):62-73

Chelcea L, Popescu R, Cristea D (2015) Who are the gentrifiers and how do they change the inner city neighborhoods: privatization, commodification and gentrification in Bucharest. Geografie 120(2):113-133

Chelcea L, Pulay G (2015) Networked infrastructures and the "local": Flows and connectivity in a postsocialist city. City 19(2-3):344-355

Cupers K (2014a) The social project. Places. https://doi.org/10.22269/140402 
Cupers K (2014b) The social project: housing in postwar France. University of Minnesota Press, Minneapolis, MN

Direcția Urbanism și Amenajarea Teritoriului (2000) Planul urbanistic general al municipiului Bucuresti

Druță O, Ronald R (2017) Young adults' pathways into homeownership and the negotiation of intra-family support: a home, the ideal gift. Sociology 51(4):783-799

Dumitru AM (2016) Apartamentul de bloc între spațiu de locuit și ,acasă’ The block flat as a living space and 'home'. In: Negru N (ed) Bucharest Hous-ing Stories. Pro Universitaria Bucharest

Fearn J (2004) Too poor to move, too poor to stay: A report on housing in the Czech Republic. Open Society Institute, Budapest, Hungary and Serbia

Fehérváry K (2013) Politics in color and concrete: socialist materialities and the middle class in Hungary. Indiana University Press, Bloomington

Fishman R (2004) Rethinking public housing. Places 16(2):16-33

Florea I (2017) To name or not to name: Contradictions in naming process in one district of Bucharest. In: Harris R, Vorms C (eds) What's in a name? Talking about urban peripheries. University of Toronto Press, Toronto

Freidrichs C (2011) The Pruitt-Igoe myth: an urban history

Graham S, Simon M (2001) Splintering urbanism: networked infrastructures, technological mobilities, and the urban condition. Routledge, London

Gusti G (1962) The influence of the new collective forms of living on the features of the socialist city, Bucharest. Arhitect Mag 2:2-5

Hirt S, Stanilov K (2007) The perils of post-socialist transformation: Residential development in Sofia. In: Stanilov K (ed) The post-socialist city: urban form and space transformations in Central and Eastern Europe after socialism. Springer, Dordrecht, pp 215-244

Iancu B (2011) The golden age of termopane. The social life of post-socialist windows. Martor 16:19-33

Institutul Naţional de Statistică. Recensămîntul populației și lo-cuințelor (2011) http://www. recensamantromania.ro/rezultate-2/

Lees L, Slater T, Wyly E (2008) Gentrification. Routledge, London

Locuinţa urbană (1962) Locuinţa urbană. Realizări din capitală 1959-1961. ed. Tehnică București

Luhn A (2017) Moscow's big move: Is this the biggest urban demolition project ever? The Guardian: Cities

Marcińczak S, Gentile M, Rufat S, Chelcea L (2014) Urban geographies of hesitant transition: Tracing socioeconomic segregation in post-ceaușescu Bucharest. Int J Urban Reg Res 38 (4):1133-1150

Marin V (2009) Politicile de locuire și planificiarea urbană: Ameliorarea lo-cuirii colective la București. Universitatea de Arhitectură and Urbanism Ioan Mincu, Bucharest, Romania

Poputoaia D, Bouzarovski S (2010) Regulating district heating in Roma-nia: legislative challenges and energy efficiency barriers. Energy Policy 38(7):3820-3829

Simion G (2016) Effects of postsocialist deindustrialization in Central and Eastern Europe: Results of an industrial site survey and GIS mapping in Bucharest city Romania. Human Geogr 10 (1):79-93

Soaita A (2012) Strategies for in-situ home improvement in Romanian large housing estates. Hous Stud 27(7):1008-1030

Stephens M, Lux M, P S (2015) Post-socialist housing systems in Europe: Housing welfare regimes by default? Hous Stud 30 (8):1210-1234

Stroe M (2015) Locuirea între proiect și decizie politică. România 1954-1966. Simetria, București

Suditu B, Dumitrache L, Vîrdol D, D.-G V (2014) New trajectories of post-socialist residential mobility in Bucharest. Human Geogr 8(1):75-82

Tudora I (2003) Le bloc, l'escalier et la communauté rêvée. Arches Mag (6) 
Tuvikene T (2018) Post-socialist (auto)mobilities: Modernity, freedom and citizenship. Geogr Comp 12(3). https://doi.org/10.1111/gec3.12362

Wacquant L (1993) Urban outcasts: Stigma and division in the Black American ghetto and the French urban periphery. Int J Urban Reg Res 17(3):366-383

van Kempen R, Dekker K, Hall S, Tosics I (2005) Restructuring large housing estates in Europerestructuring and resistance inside the welfare industry. Policy Press, University of Bristol, Bristol

Open Access This chapter is licensed under the terms of the Creative Commons Attribution 4.0 International License (http://creativecommons.org/licenses/by/4.0/), which permits use, sharing, adaptation, distribution and reproduction in any medium or format, as long as you give appropriate credit to the original author(s) and the source, provide a link to the Creative Commons license and indicate if changes were made.

The images or other third party material in this chapter are included in the chapter's Creative Commons license, unless indicated otherwise in a credit line to the material. If material is not included in the chapter's Creative Commons license and your intended use is not permitted by statutory regulation or exceeds the permitted use, you will need to obtain permission directly from the copyright holder. 